\title{
THE AMOUNT OF LICHEN SECONDARY METABOLITES IN CLADONIA FOLIACEA (CLADONIACEAE, LICHENISED ASCOMYCOTA)
}

\author{
E. Farkas ${ }^{1 *}$, B. Biró ${ }^{1}$, K. Szabó ${ }^{1}$, K. Veres ${ }^{1,2},+$ Zs. Csintalan ${ }^{2}$ and R. Engel ${ }^{1}$ \\ ${ }^{1}$ Laboratory for Lichenology and Phytochemistry, Institute of Ecology and Botany \\ MTA Centre for Ecological Research, H-2163 Vácrátót, Alkotmány u. 2-4, Hungary \\ E-mail: farkas.edit@okologia.mta.hu, ${ }^{*}$ corresponding author \\ ${ }^{2}$ Institute of Botany and Ecophysiology, Szent István University \\ H-2100 Gödöllö, Páter K. u. 1, Hungary
}

(Received 13 October 2019; Accepted 28 November 2019)

The terricolous species Cladonia foliacea (Cladoniaceae, lichenised Ascomycota) widely distributed in open, dry lowland steppe and rocky mountain grassland vegetation in Europe was chosen as a potential test organism for ecological experiments, since their thalli are producing cortical solar radiation-protective and UV screening pigment dibenzofuran usnic acid and medullary secondary substance depsidone fumarprotocetraric acid. Significant seasonal differences were found in the amounts of lichen secondary metabolites analysed by HPTLC and HPLC-PDA between summer and winter collected thalli in sandy grassland area in Hungary. The concentrations of usnic acid varied between 7.34 and 15.52 $\mathrm{mg} / \mathrm{g}$ in summer collected samples and 13.90 and $21.61 \mathrm{mg} / \mathrm{g}$ in winter collected ones. A comparable amount $(11.61 \pm 0.29 \mathrm{mg} / \mathrm{g})$ was measured in pulverised samples. The concentrations of fumarprotocetraric acid varied between 0.60 and $3.01 \mathrm{mg} / \mathrm{g}$ in summer collected samples and 2.26 and $5.81 \mathrm{mg} / \mathrm{g}$ in winter collected thalli. A comparable amount $(2.45 \pm 0.21$ $\mathrm{mg} / \mathrm{g}$ ) was found in pulverised samples. The range of concentration values is comparable with data known from lichens. A higher amount of usnic acid is produced in winter probably to ensure sufficient protection also for summer. The fumarprotocetraric acid content of the medulla might contribute to the solar irradiation reflecting role of the pale lower surface lobes turning upwards in dry condition.

Key words: acetone rinsing, chlorolichens, fumarprotocetraric acid, high performance liquid chromatography with photodiode array detector (HPLC-PDA), seasonal differences, usnic acid

\section{INTRODUCTION}

Lichenised associations represent a sensitive model ecosystem for investigating various or changed environmental conditions (cf. Asplund et al. 2017, Bergamini et al. 2005, Galloway 1993, Nash 2008, Stofer et al. 2006). Lichens produce a great variety of lichen secondary metabolites (LSMs), and most of them are unique to lichen-forming fungi as it is summarised in recent reviews on their biological roles (Calcott et al. 2018, Molnár and Farkas 2010). 
Approximately 1,050 secondary compounds have been identified to date (Stocker-Wörgötter 2008, 2015). These chemically diverse (aliphatic and aromatic) lichen substances are produced by the mycobiont (Elix 1996, Huneck 1999). Some of them (such as atranorin, parietin, usnic acid or fungal melanins) are accumulated in the cortex, others (such as norstictic acid, physodic acid, physodalic acid, protocetraric acid, etc.) are detected as tiny extracellular crystals within and on the proteinaceous hydrophobic wall surface layer of the hyphae in the medullary and photosynthetic layer (also on photobiont wall surface) (Honegger 1986, 1997, 2012).

Lichen secondary chemistry analyses - and study of their relation to environmental conditions (cf. Armaleo et al. 2008, Asplund et al. 2017, Hauck 2011, Hauck et al. 2009, Matteucci et al. 2017, Shukla et al. 2016) - clarify the background of the chemical diversity of the studied taxa.

Most of the LSMs can be removed by acetone as it is applied in chromatographic investigations of these substances (Arup et al. 1993, Feige et al. 1993, Huneck and Yoshimura 1996, Orange et al. 2010). According to Solhaug and Gauslaa $(1996,2001)$ both mycobiont and photobiont were able to survive acetone rinsing treatment. Removing lichen substances from dry lichen thalli by pure acetone - compared to other solvents - is regarded as the least detrimental method (Solhaug and Gauslaa 2001). Acetone rinsed samples continued producing secondary lichen substances (Solhaug and Gauslaa 2004) and pigment composition did not alter after treatment (Candotto Carniel et al. 2017).

The lichen species Cladonia foliacea is a frequent chlorolichen in open, dry, sun-exposed habitats in the Hungarian lowland steppe areas as well as in low mountain rocky grasslands. Since it has a great potential in experimental applications, it was selected for a test organism and tested for its tolerance for acetone treatment (Farkas et al. 2020). Our present aim was to check LSM content of exactly the same thalli by the analysis of the soaking acetone-solution, furthermore to study seasonal differences in samples collected in two seasons, summer and winter.

\section{MATERIALS AND METHODS}

\section{Chemicals}

All chemicals were of analytical or higher grade. HPLC acetone (VWR) was applied to extract LSMs from intact lichen samples and for chromatographic analysis (HPLC $=$ High Performance Liquid Chromatography, HPTLC $=$ High Performance Thin Layer Chromatography, see also below). Toluene (CARLO ERBA Reagents), acetic acid (Lach-Ner) and sulphuric acid (CARLO ERBA Reagents) were obtained from Reanal for HPTLC investiga- 
tions. Acetonitrile (VWR) and ortho-phosphoric acid (Merck) were used for HPLC analysis. Aqueous solutions were prepared with Milli-Q-water (Millipore). Usnic acid was purchased from Sigma Aldrich, fumarprotocetraric acid from Phytolab. Reagents for spot reactions are $\mathrm{Pd}=\mathrm{p}$-phenylene-diamine (Sigma Aldrich), $\mathrm{K}=\mathrm{KOH}$ (Reanal), and $\mathrm{C}=$ commercial bleach, for $\mathrm{KC}$ reaction $\mathrm{K}$ and $\mathrm{C}$ applied sequentially, $\mathrm{K}$ followed immediately after by $\mathrm{C}$ (for preparation of reagents and further details on spot tests see Orange et al. 2010).

\section{The research object}

Cladonia foliacea (Huds.) Willd. (Cladoniaceae, lichenised Ascomycota) (Fig. 1) is a relatively frequent, terricolous, foliose lichen species in Hungary and widely distributed over Europe both in open, dry and sun-exposed habitats in lowland steppe and mountain grassland communities, also found in northern hemisphere temperate region in North America (Smith et al. 2009, Wirth et al. 2013). The different LSM content of the cortex (KC+ pale yellow for usnic acid) and the medulla ( $\mathrm{Pd}+$ yellow to red for fumarprotocetraric acid) was already indicated by spot tests (Hillmann and Grummann 1957). The thallus has a thickened upper cortex containing usnic acid (Fig. 1) as a protective compound against UV radiation and other effects (e.g. Cochietto et al. 2002, Yilmaz et al. 2004). The photosynthetic layer contains coccoid green alga photobiont (Asterochloris sp., Trebouxiaceae - cf. Moya et al. 2015, Peksa and Skaloud 2008, Škaloud and Peksa 2008). The yellowish white, white lower surface lobes are turning upwards when they are dry and reflecting the strong solar irradiation near soil surface. The species also produces a depsidone, the fumarprotocetraric acid (Fig. 1) here in the medullary layer. There is no lower cortical layer developed.

Various effects of these LSMs are investigated in detail analysing extracts of this species (e.g., Anar et al. 2013, Aslan et al. 2006, Emsen et al. 2012, Khadri et al. 2019, Koparal 2015, Kosanić et al. 2018, Mitrović et al. 2011, 2015, Pandir et al. 2018, Yilmaz et al. 2004).

\section{Collection and treatments of the samples}

Lichen thalli were collected in summer (16 June 2015) and in winter (13 January 2016) in the plant association Festucetum vaginatae Rapaics ex Soó 1929 em. Borhidi 1996 (Borhidi et al. 2012) lowland steppe open sandy perennial grassland (Pannonian psammophytic grasslands) area Tece of Vácrátót. Voucher specimens (VBI-L 6104, 6105) are deposited in the VBI Lichen Herbarium (Vácrátót, Hungary). The thalli were dried, cleaned and randomised at room temperature $\left(24-26^{\circ} \mathrm{C}\right)$, then $2-4$ entire thalli or parts of thalli (20-25 
$\mathrm{mm} \times 20-40 \mathrm{~mm} \times 8-12 \mathrm{~mm}$ ) were placed in $50 \mathrm{ml}$ Falcon tubes where acetone rinsing was applied. Lichens were kept in dry, inactive condition before acetone rinsing. The dry weight of lichen samples ( $c a 1 \mathrm{~g})$ and also the volume of the acetone $(40 \mathrm{ml})$ were measured for each replicates (of 6/treatments used for HPLC analyses - see under HPLC method). The durations of soaking (13 different treatments) were the same as applied by Solhaug and Gauslaa (2001), so that is between $30 \mathrm{~min}$ and nearly 6 weeks: $0.5,1,2,4,8,16,32$, 64, $128,256,384,640$ and 1,024 hrs. After removing the thalli from acetone, the soaking acetone-solution was analysed by HPLC.

\section{HPTLC method}

Collected samples were checked for presence of usnic acid and fumarprotocetraric acid by high performance thin layer chromatography (HPTLC) according to standard methods for analysing lichen samples described by Arup et al. (1993) and Molnár and Farkas (2011). CAMAG horizontal chamber of $10 \mathrm{~cm} \times 10 \mathrm{~cm}$, CAMAG TLC Plate Heater III, $10 \mathrm{~cm} \times 10 \mathrm{~cm}$ thin-layer chromatographic plates (Merck, Kieselgel 60 F254) were used. Solvent system C (toluene-acetic acid, 20:3) was applied.

\section{HPLC method}

LSM containing acetone solutions remained after acetone rinsing treatment were analysed by high performance liquid chromatography with photodiode array detector HPLC-PDA. We used a Waters HPLC (e2695) equipped with Photodiode Array Detector (2998 PDA Detector).

Six replicates were applied for each of the 13 treatments (different duration of time for soaking in acetone). The acetone-rinsed lichen thalli were used for fluorescence measurements and LSMs originating from the same thalli were analysed from the soaking acetone. In this way acetone-solution of randomised entire thalli and parts of thalli were sampled. According to our aim we intended to check LSM content of the same thalli - which were used for chlorophyll fluorescence measurement - by the analysis of the soaking acetone-solution.

We tested acetone extraction also on pulverised homogenised samples according to protocol of preparative pharmaceutical analytical investigations. Acetone is a strong organic solvent and it was not surprising that there was no difference between samples extracted for 15, 30, 40 and $50 \mathrm{~min}$. Homogenisation was carried out on lyophylised samples - for $72 \mathrm{hr}$ lyophylisation a freeze dryer Christ Beta 1-8 (with vacuum pump Edwards RV5) was used adjusting condenser temperature to $-50{ }^{\circ} \mathrm{C}$, vacuum to $3 \times 10^{-2} \mathrm{mbar}$. 
The following chromatographic conditions were applied for measuring usnic acid and fumarprotocetraric acid (modified design after Ji and Khan 2005).

Chromatographic separation was carried out on a Phenomenex Luna, $4.6 \times 150 \mathrm{~mm}, 5 \mu \mathrm{m}$ column. The column oven temperature was $40^{\circ} \mathrm{C}$ and the sample cooler temperature was $5{ }^{\circ} \mathrm{C}$. For elution, $0.5 \%(\mathrm{v} / \mathrm{v})$ ortho-phosphoric acid in water (mobile phase A) and $0.5 \%$ (v/v) ortho-phosphoric acid in acetonitrile (mobile phase $B$ ) were used as solvents at a flow rate of $1 \mathrm{~mL} / \mathrm{min}$.

The duration of the gradient program was $45 \mathrm{~min}$. The gradient program started at $40 \%$ B, and after 2 min of isocratic run, solvent B was increased linearly and reached $99.5 \%$ at $5 \mathrm{~min}$. Finally, $99.5 \%$ B was kept constant for 5 min before getting back to initial conditions to equilibrate the LC before the next injection. Two detection wavelength $\lambda=280 \mathrm{~nm}$ for usnic acid and $\lambda=240$ $\mathrm{nm}$ for fumarprotocetraric acid were chosen based on their UV-Vis spectra. Under the described chromatographic conditions the retention times of the compounds of interest were $6.36 \mathrm{~min}$ for fumarprotocetraric acid and 15.24

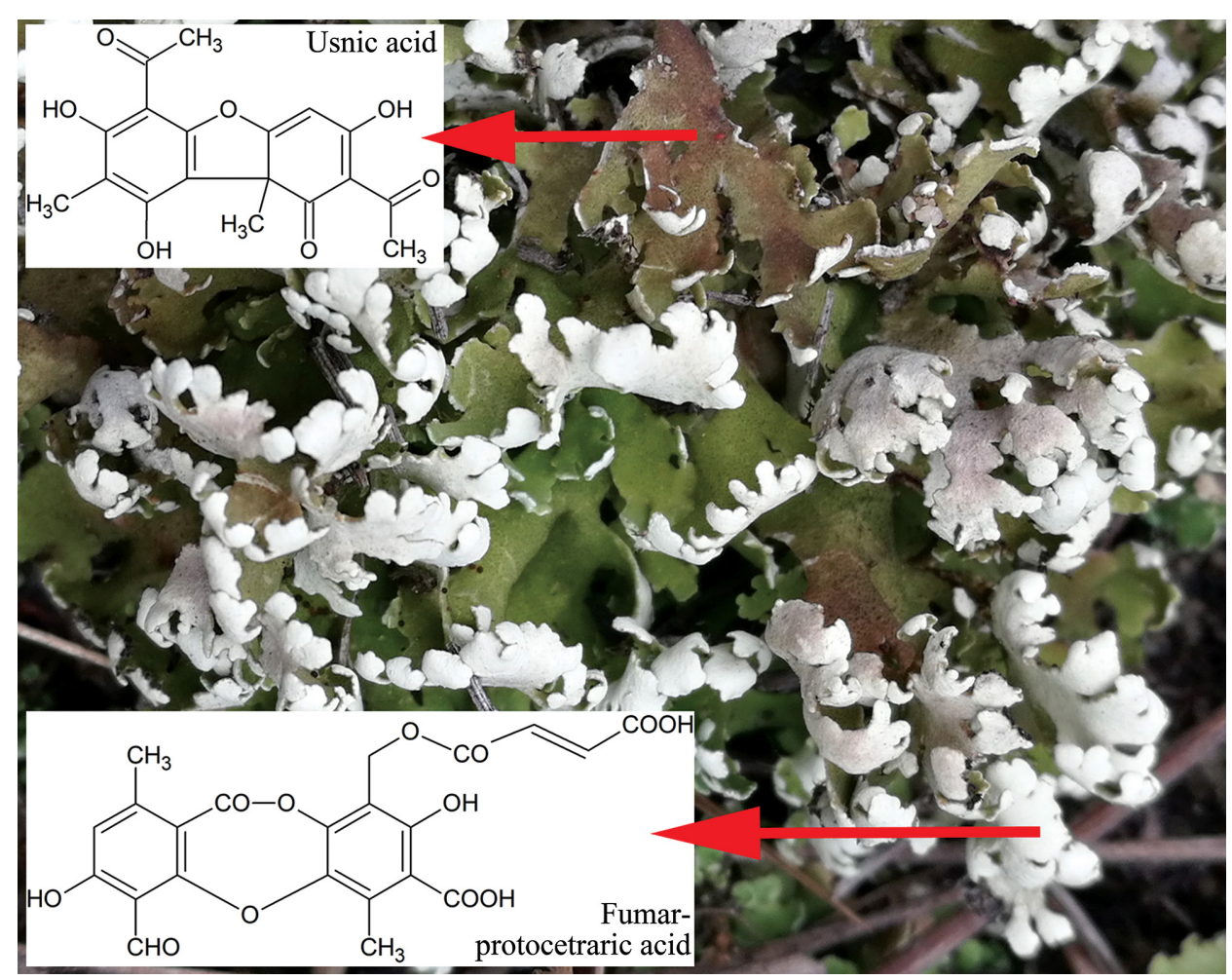

Fig. 1. Cladonia foliacea lichen thallus with usnic acid in upper cortex and fumarprotocetraric in lower medullary layer 
$\min$ for usnic acid. The sample injection volume was $10 \mu \mathrm{L}$. Before injection to the HPLC the samples were filtered (Cronus $25 \mathrm{~mm}$ PTFE Syringe Filter 0.22 $\mu \mathrm{m})$. For calibration standard stock solutions $(1,000 \mu \mathrm{g} / \mathrm{mL})$ were prepared from usnic acid and fumarprotocetraric acid reference standards dissolved in acetone. Usnic acid and fumarprotocetraric acid were quantified based on a five-point $(5,10,20,50,100 \mu \mathrm{g} / \mathrm{mL})$ calibration.

\section{Statistics}

One-way ANOVA followed by Tukey HSD post-hoc tests were applied for LSM concentrations to compare the treatment groups (by seasons). Pearson's rank correlation (R Core Team, 2013) was applied for analysing concentration values of LSMs.

\section{RESULTS AND DISCUSSION}

Two major LSMs, depsidone fumarprotocetraric acid and dibenzofuran usnic acid are produced by C. foliacea (Hillmann and Grummann 1957, Huneck and Yoshimura 1996, Smith et al. 2009, Wirth et al. 2013). The presence of these substances was checked by high-performance thin-layer chromatography (HPTLC). Quantitative analysis was carried out by high-performance liquid chromatography with photodiode array detector (HPLC-PDA).

The concentration of usnic acid measured in a series of acetone rinsed thalli was somewhat higher in winter than in summer collected samples (Fig. 2). The concentrations varied between 7.34 and $15.52 \mathrm{mg} / \mathrm{g}$ in summer collected samples and 13.90 and $21.61 \mathrm{mg} / \mathrm{g}$ in winter collected samples. Variance analysis $(p=0.05)$ showed significant difference in winter samples only at a few (3 out of 13) treatments, in summer samples at somewhat more (7 out of 13) treatments (Table 1). In majority the concentrations in the samples did not differ significantly within treatments. However, significant difference was found between the summer and winter samples in majority (11 out of 13) of the treatments (Table 3).

A comparable amount $(11.61 \pm 0.29 \mathrm{mg} / \mathrm{g})$ was measured also in the lyophilised, homogenised samples collected in summer.

The higher amount of UV protecting usnic acid measured in winter collected samples might be explained by the longer humid periods accompanied by higher amount of incoming light in this period of year compared to summer environmental conditions (cf. Ertl 1951). The photobionts need more intense protection against harmful light in hydrated, unfolded thallus, therefore the production of this type of LSM might be increased (cf. Gauslaa et al. 2017, Vráblíková et al. 2006). In contrast lichens are photosynthetically active only 


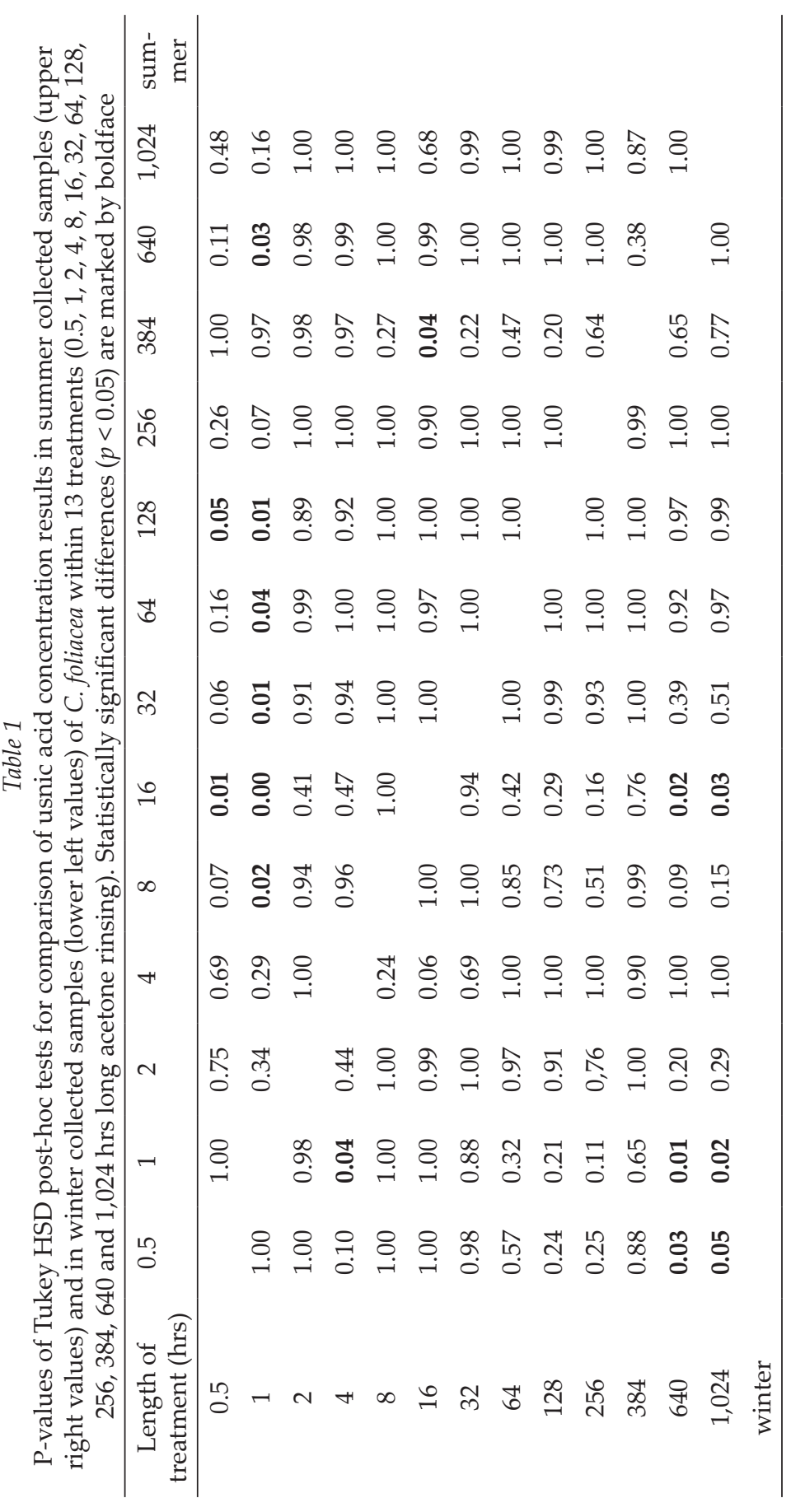




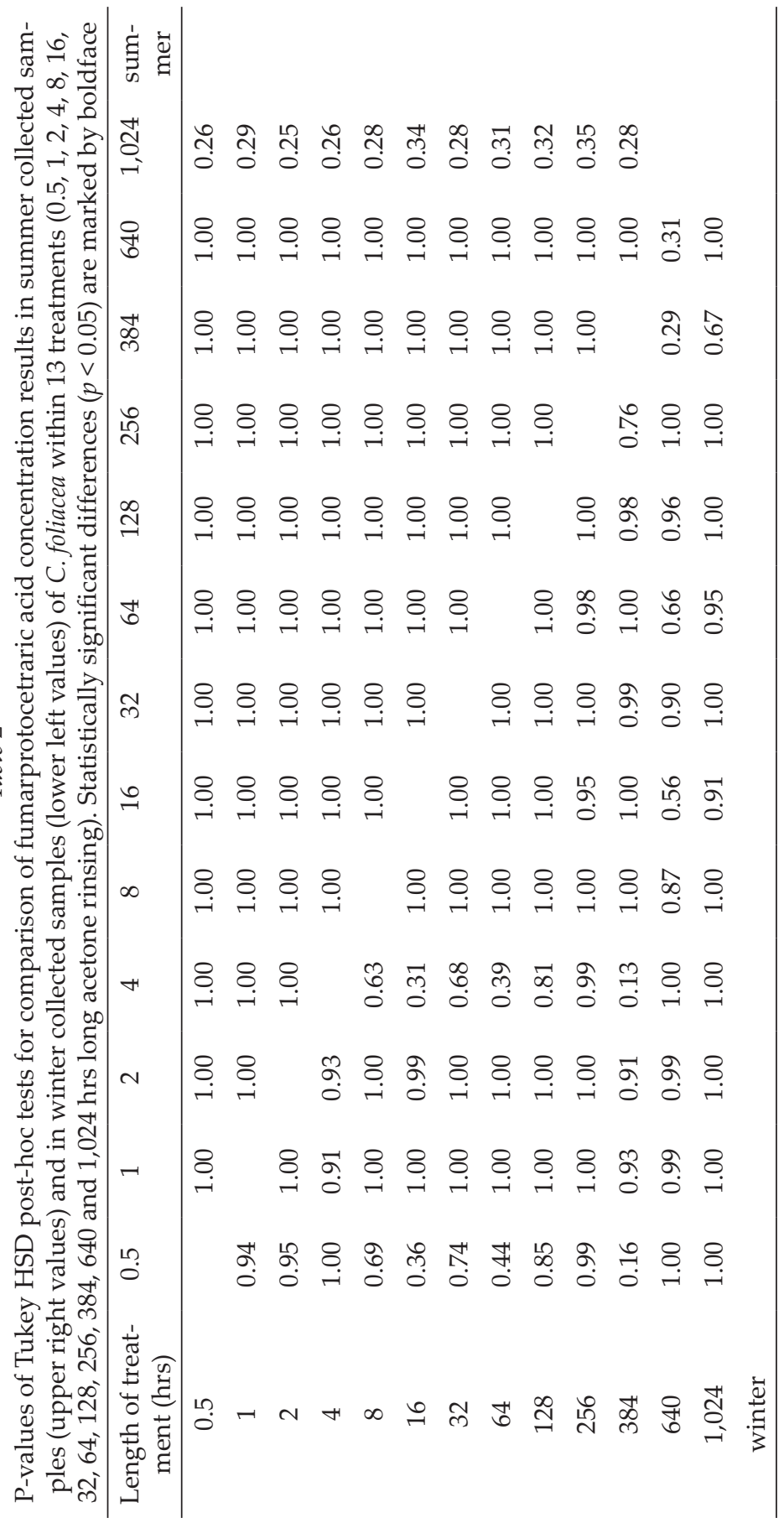


Table 3

P-values testing differences between the usnic acid $(\mathrm{mg} / \mathrm{g})$ and fumarprotocetraric acid content $(\mathrm{mg} / \mathrm{g})$ of summer and in winter collected $C$. foliacea thalli after $0.5,1,2,4,8,16$, $32,64,128,256,384,640$ and $1,024 \mathrm{hrs}$ long acetone rinsing. Statistically significant differences are marked with asterisks $\left({ }^{* * *}=p<0.05,{ }^{* *}=0.1<p<0.05\right) ; \mathrm{n}=6$

\begin{tabular}{ccccc}
\hline Length of treatment $(\mathrm{hrs})$ & $\mathrm{p}_{\text {usnic acid }}$ & & $\mathrm{p}_{\text {fumarprotocetraric acid }}$ & \\
\hline 0.5 & 0.896 & & 0.103 & $* * *$ \\
1 & 0.365 & & 0.003 & $* * *$ \\
2 & 0.037 & $* * *$ & 0.001 & $* * *$ \\
4 & 0.000 & $* * *$ & 0.043 & $* * *$ \\
8 & 0.026 & $* * *$ & 0.043 & $* * *$ \\
16 & 0.011 & $* * *$ & 0.006 & $* * *$ \\
32 & 0.005 & $* * *$ & 0.053 & \\
64 & 0.005 & $* * *$ & 0.034 & \\
128 & 0.001 & $* * *$ & 0.157 & \\
256 & 0.005 & $* * *$ & 0.674 & \\
384 & 0.023 & $* * *$ & 0.009 & \\
640 & 0.001 & $* * *$ & 0.749 & \\
1,024 & 0.037 & $* * *$ & 0.810 &
\end{tabular}

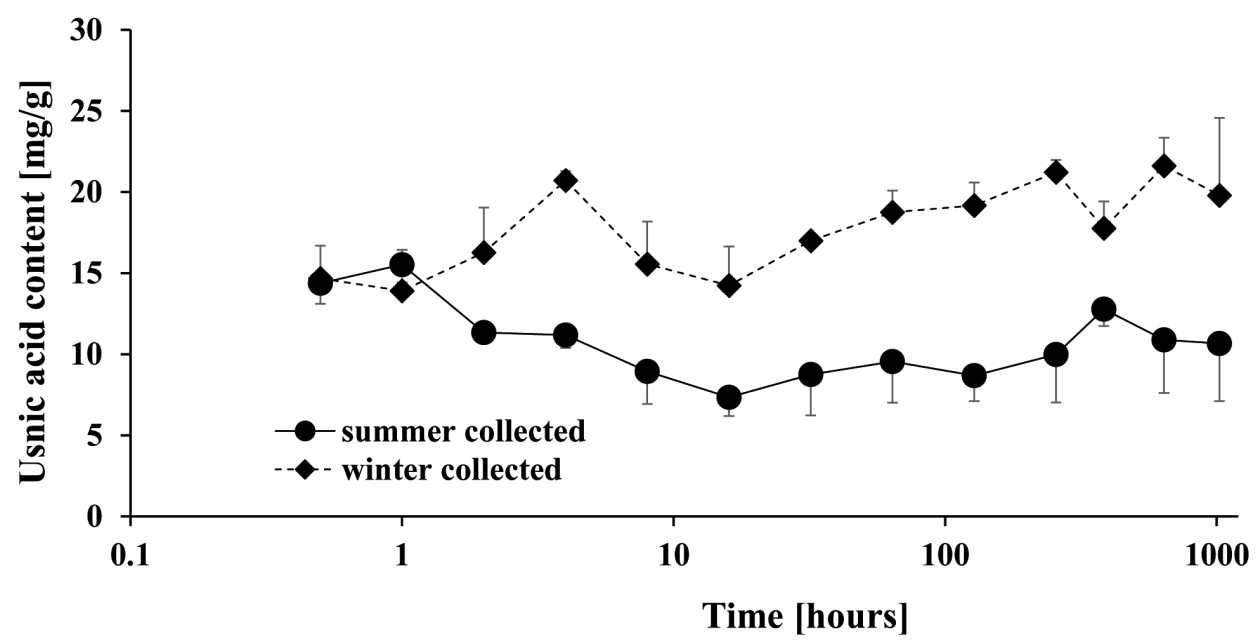

Fig. 2. Relation between usnic acid content ( $\mathrm{mg} / \mathrm{g})$ and the duration of acetone rinsing (hrs) of Cladonia foliacea samples collected in summer $(n=6)$ and winter $(n=6)$ (error bars show standard deviations) 
for a few hours early in the morning in summer according to former measurements carried out also in Hungarian Great Plain (Kalapos and Mázsa 2001, Lange et al. 1970, Mázsa 1994, Mázsa et al. 1998, 1999). At this time thalli are wet because of dawn dew, but a few hours after sunrise they dry out quickly (Kalapos and Mázsa 2001, Lange et al. 1970, Verseghy et al. 1987). Thalli needed less intense photoprotection, and fewer amounts of UV protecting metabolites against harmful excess light. Bjerke et al. (2005), finding 51.1 to 53 $\mathrm{mg} / \mathrm{g}$ usnic acid in Arctic, alpine and Patagonian populations of another species (Flavocetraria nivalis (L.) Kärnefelt et A. Thell), reported large variations among samples. BeGora and Fahselt (2001) found that usnic acid production in Cladina arbuscula subsp. mitis (Sandst.) Burgaz was the lowest at sampling times when the highest UV-B radiation was detected.

There is a similar tendency in fumarprotocetraric acid concentrations (Fig. 3): the winter collected values are above the summer collected values at each treatment. The concentrations varied between 0.60 and $3.01 \mathrm{mg} / \mathrm{g}$ in summer collected samples and 2.26 and $5.81 \mathrm{mg} / \mathrm{g}$ in winter collected samples. Neither summer, nor winter values differed significantly within the 13 treatments (Table 2). However, significant difference was found between the summer and winter treatments in majority (7 out of 13) of the treatments (Table 3).

A comparable amount $(2.45 \pm 0.21 \mathrm{mg} / \mathrm{g})$ was measured also in the lyophilised, homogenised samples collected in summer.

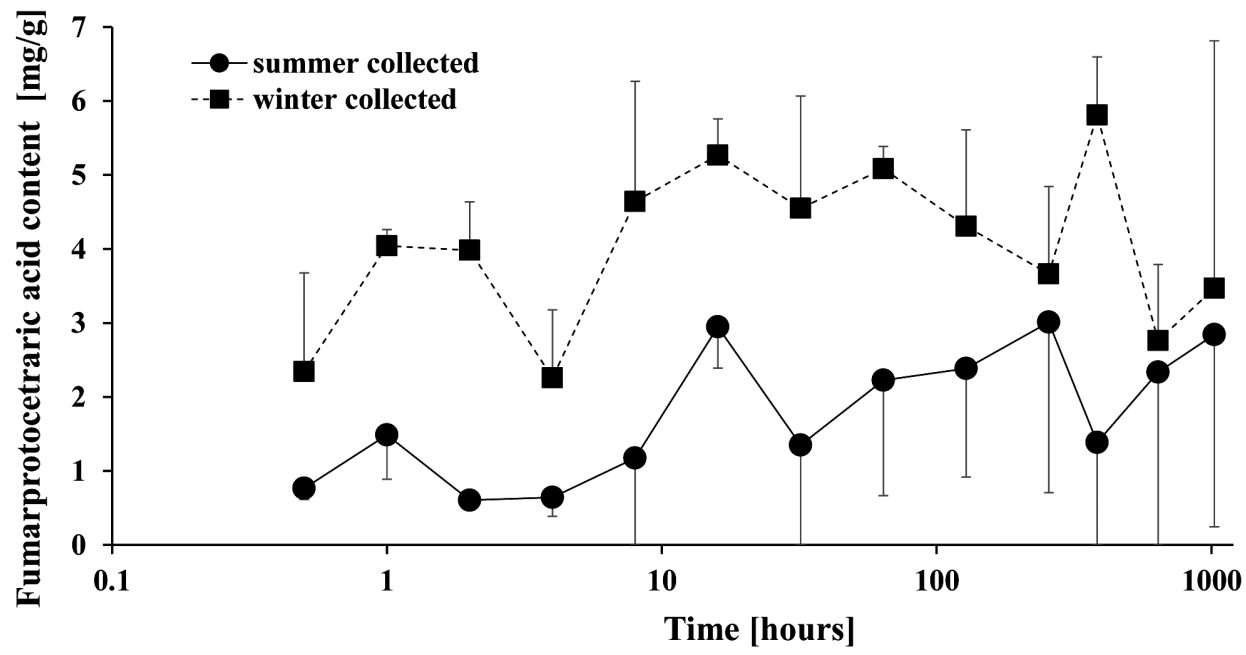

Fig. 3. Relation between fumarprotocetraric acid content $(\mathrm{mg} / \mathrm{g})$ and the duration of acetone rinsing (hrs) of Cladonia foliacea samples collected in summer $(n=6)$ and winter $(n=6)$ related to (error bars show standard deviations) 
These values are very similar to data $(0.11-5.4 \mathrm{mg} / \mathrm{g})$ given by Archer (1981) for Australian scyphose Cladonia species (collected between October 1978 and February 1980).

There is a significant difference between concentrations of the summer and winter collected samples in respect of both usnic and fumarprotocetraric acids (Table 3). In case of usnic acid concentration values differed considerably, except for short treatments $(0.5-1 \mathrm{hr})$. Collecting season is somewhat more important for fumarprotocetraric acid, if short treatment is applied, however at the long (128-1,024 hrs) treatments with acetone, fumarprotocetraric acid contents did not differ significantly.

In the same time there is a weak negative correlation between the usnic acid and fumarprotocetraric acid concentration values both in summer ( $\mathrm{r} 2=$ $0.28)$ and in winter $(\mathrm{r} 2=0.17)$. This result might be caused by the special morphology of $C$. foliacea thalli changing with humidity conditions. If samples (placed in a single Falcon tube) contained more thalli, parts of thalli which was effected by irradiance on their upper surface (usnic acid containing upper cortex) for longer time, the concentration of usnic acid was relatively higher and that of fumarprotocetraric acid was lower. If there was relatively more of the enrolled pale lower surface (where the production of fumarprotocetraric acid is characteristic in the medulla) which was effected by irradiance for a longer time, a slightly higher fumarprotocetraric acid content could be detected compared to the amount of usnic acid. The moderate variability within treatments found by variance analysis justifies that HPLC measurements of the soaking acetone provides valuable results.

The detrimental effect of acetone tested by chlorophyll fluorescence measurement resulted in tolerance until ca 5 days (Farkas et al. 2020). The slight seasonal difference between the summer and winter collected thalli is not significant in this respect.

HPLC measurements show moderate variability for usnic acid and no significant variability for fumarprotocetraric acid in the measured values, thus variance analysis $(p=0.05)$ resulted in significant difference both within the winter and summer samples only at a few treatments in usnic acid concentrations. However there is a significant difference between concentrations of summer and winter collected samples in respect of both usnic and fumarprotocetraric acids. Thalli contain relatively more usnic acid and fumarprotocetraric acid in winter than in summer. It must be considered, that while little is known about the metabolism of these substances, it was justified (P.Verseghy 1976) that the thickness of thalline layers of some temperate xerophilous Cladonia species (incl. C. foliacea - as C. convoluta in the cited paper) is changing by seasons. Therefore it may be supposed that the summer and winter collected thalli were different in the terms of their thalline layer com- 
position. Furthermore the moderate water solubility of fumarprotocetraric acid has been observed by us during HPTLC studies, therefore this substance must have a considerable dynamics during the shift of rainy and dry periods (Burgaz, pers. comm.).

The usnic acid containing cortex protects the photobionts from UV irradiation, since usnic acid may act as UV screening agent or have solar radiation protective function (Galloway 1993, McEvoy et al. 2007, Nguyen et al. 2013, Nybakken et al. 2004, 2007). It seems so from the results, that a higher amount of usnic acid is produced in winter to ensure sufficient protection also for summer due to the less amount of harmful incident light. The UV protecting role has not been reported for fumarprotocetraric acid. However, according to our hypothesis the fumarprotocetraric acid content of the medulla might contribute to the solar irradiation reflecting role of the pale lower surface lobes turning upwards in dry condition. Since the range of concentration values originating from the analysis of the soaking acetone-solution is comparable with amounts found in pulverised samples, as well as with data known from lichens previously, these data represent valuable contribution to the knowledge on production of these LSMs in this particular species and forms a basis for further comparative investigations.

Acknowledgements - Authors are grateful for Mrs Sándorné Vadkerti (Vácrátót) for technical help during collecting specimens in the field. Dr Csaba Locsmándi (Budapest) kindly provided help with lyophilisation of samples. Dr Katalin Molnár (Komárom), Mrs Nóra Varga (Vácrátót) and Dr László Lőkös (Budapest) are thanked for reading the manuscript. This work was supported by the Hungarian Scientific Research Fund (OTKA 81232 - PI: EF, 101713 - PI: ZsCs), the Research Centre of Excellence (11476-3/2016/FEKUT for ZsCs and KV) and the project financed by the National Research Development and Innovation Fund (NKFI K 124341 - PI: EF). The travel grant of the British Lichen Society made a contribution towards a presentation (by EF) on this research during IAL8 2016.

\section{REFERENCES}

Anar, M., Orhan, F., Alpsoy, L., Gulluce, M., Aslan, A. and Agar, G. (2013): The antioxidant and antigenotoxic potential of methanol extract of Cladonia foliacea (Huds.) Willd. Toxicol. Indust. Health 32(4): 721-729. https://doi.org/10.1177/0748233713504805

Archer, A. W. (1981): Quantitative distribution of lichen products in Australian scyphose Cladonia species. - Lichenologist 13: 259-263. https://doi.org/10.1017/s0024282981000340

Armaleo, D., Zhang, Y. and Cheung, S. (2008): Light might regulate divergently depside and depsidone accumulation in the lichen Parmotrema hypotropum by affecting thallus temperature and water potential. - Mycologia 100(4): 565-576. https://doi. org/10.3852/07-162r 
Arup, U., Ekman, S., Lindblom, L. and Mattsson, J.-E. (1993): High performance thin layer chromatography (HPTLC), an improved technique for screening lichen substances. Lichenologist 25(1): 61-71. https://doi.org/10.1006/lich.1993.1018

Aslan, A., Güllüce, M., Sökmen, M., Adıgüzel, A., Şahin, F. and Özkan, H. (2006): Antioxidant and antimicrobial properties of the lichens Cladonia foliacea, Dermatocarpon miniatum, Evernia divaricata, Evernia prunastri and Neofuscelia pulla. - Pharm. Biol. 44(4): 247-252. https://doi.org/10.1080/13880200600713808

Asplund, J., Siegenthaler, A. and Gauslaa, Y. (2017): Simulated global warming increases usnic acid but reduces perlatolic acid in the mat-forming terricolous lichen Cladonia stellaris. - Lichenologist 49(3): 269-274. https://doi.org/10.1017/s0024282917000159

BeGora, M. D. and Fahselt, D. (2001): Usnic acid and atranorin concentrations in lichens in relation to bands of UV irradiance. - The Bryologist 104(1): 134-140. https://doi. org/10.1639/0007-2745(2001)104[0134:uaaaci]2.0.co;2

Bergamini, A., Scheidegger, C., Stofer, S. et al. (2005): Performance of macrolichens and lichen genera as indicators of lichen species richness and composition. - Conservation Biol. 19(4): 1051-1062. https://doi.org/10.1111/j.1523-1739.2005.00192.x-i1

Bjerke, J. W., Elvebakk, A., Dominguez, E. and Dahlback, A. (2005): Seasonal trends in usnic acid concentrations of Arctic, alpine and Patagonian populations of the lichen Flavocetraria nivalis. - Phytochemistry 66: 337-344. https://doi.org/10.1016/j.phytochem.2004.12.007

Borhidi, A., Kevey, B. and Lendvai, G. (2012): Plant communities of Hungary. - Akadémiai Kiadó, Budapest, 544 pp.

Calcott, M. J., Ackerley, D. F., Knight, A., Keyzers, R. A. and Owen, J. G. (2018): Secondary metabolism in the lichen symbiosis. - Chem. Soc. Reviews 47(5): 1730-1760. https://doi. org/10.1039/c7cs00431a

Candotto Carniel, F., Pellegrini, E., Bove, F. and Crosera, M. (2017): Acetone washing for the removal of lichen substances affects membrane permeability. - Lichenologist 49(4): 387-395. https://doi.org/10.1017/s0024282917000263

Cocchietto, M., Skert, N., Nimis, P. L. and Sava, G. (2002): A review on usnic acid, an interesting natural compound. - Die Naturwissenschaften 89: 137-146. https://doi. org/10.1007/s00114-002-0305-3

Elix, J. A. (1996): Biochemistry and secondary metabolites. - In: Nash III, T. H. (ed.): Lichen biology, 1st ed. Cambridge University Press, Cambridge, pp. 155-180.

Emsen, B., Yıldırım, E., Aslan, A., Anar, M. and Ercişli, S. (2012): Insecticidal effect of the extracts of Cladonia foliacea (Huds.) Willd. and Flavoparmelia caperata (L.) Hale against adults of the grain weevil, Sitophilus granarius (L.) (Coleoptera: Curculionidae). - Egypt. J. Biol. Pest Cont. 22(2): 145-149.

Ertl, L. (1951): Über die Lichtverhältnisse in Laubflechten. - Planta 39(3): 245-270. https:// doi.org/10.1007/bf01909397

Farkas, E., Biró, B., +Csintalan, Zs. and Veres, K. (2020): Acetone rinsing tolerance of the lichen species Cladonia foliacea is considerable. - Lichenologist, in prep.

Feige, B., Lumbsch, H. T., Huneck, S. and Elix, J. A. (1993): Identification of lichen substances by standardized high-performance liquid chromatographic method. - J. Chromatogr. 646: 417-427. https://doi.org/10.1016/0021-9673(93)83356-w

Galloway, D. J. (1993): Global environmental change: lichens and chemistry. - In: Feige, G. B. and Lumbsch, H. T. (eds): Phytochemistry and chemotaxonomy of lichenized Ascomycetes. A Festschrift in honour of Siegfried Huneck. J. Cramer, Berlin, Stuttgart, Bibl. Lichenol. 53: 87-95. 
Gauslaa, Y., Azharul Alam, Md., Lucas, P.-L., Chowdhury, D. P. and Solhaug, K. A. (2017): Fungal tissue per se is stronger as a UV-B screen than secondary fungal extrolites in Lobaria pulmonaria. - Fungal Ecol. 26: 109-113. https://doi.org/10.1016/j.funeco.2017.01.005

Hauck, M. (2011): Eutrophication threatens the biochemical diversity in lichens. - Lichenologist 43: 147-154. https://doi.org/10.1017/s0024282910000654

Hauck, M., Willenbruch, K. and Leuschner, C. (2009): Lichen substances prevent lichens from nutrient deficiency. - J. Chem. Ecol. 35: 71-73. https://doi.org/10.1007/s10886008-9584-2

Hillmann, J. and Grummann, V. (1957): Kryptogamenflora der Mark Brandenburg und angrenzender Gebiete. Band VIII: Flechten. - Gebrüder Borntraeger, Berlin-Nikolassee, 898 pp.

Honegger, R. (1986): Ultrastructural studies in lichens. II. Mycobiont and photobiont cell wall surface layers and adhering crystalline lichen products in four Parmeliaceae. New Phytol. 103: 797-808. https://doi.org/10.1111/j.1469-8137.1986.tb00854.x

Honegger, R. (1997): Metabolic interactions at the mycobiont-photobiont interface in lichens. - In: Carroll, G. C. and Tudzynski, P. (eds): The Mycota V. Plant relationships. Springer, Berlin, Heidelberg, New York, pp. 209-221.

Honegger, R. (2012): The symbiotic phenotype of lichen-forming ascomycetes and their endo- and epibionts. - In: Hock, B. (ed.): The Mycota IX. Fungal Associations. Springer, Berlin, Heidelberg, pp. 287-339.

Huneck, S. (1999): The significance of lichens and their metabolites. - Die Naturwissenschaften 86: 559-570. https://doi.org/10.1007/s001140050676.

Huneck, S. and Yoshimura, I. (1996): Identification of lichen substances. - Springer Verlag, Berlin, Heidelberg, 493 pp.

Ji, X. and Khan, I. A. (2005): Quantitative determination of usnic acid in Usnea lichen and its products by reversed-phase liquid chromatography with photodiode array detector. - J. AOAC Int. 88(5): 1265-1268.

Kalapos, T. and Mázsa, K. (2001): Juniper shade enables terricolous lichens and mosses to maintain high photochemical efficiency in a semiarid temperate sand grassland. Photosynthetica 39(2): 263-268. https://doi.org/10.1023/a:1013749108008

Khadhri, A., Mendili, M., Araújo, M. E. M. and Seaward, M. R. D. (2019): Comparative study of secondary metabolites and bioactive properties of the lichen Cladonia foliacea with and without the lichenicolous fungus Heterocephalacria bachmannii. Symbiosis 79(1): 25-31. https://doi.org/10.1007/s13199-019-00630-6

Koparal, A. T. (2015): Anti-angiogenic and antiproliferative properties of the lichen substances (-)-usnic acid and vulpinic acid. - Z. Naturforsch., Sect. C 70(5-6): 159-164. https://doi.org/10.1515/znc-2014-4178

Kosanić, M., Ristić, S., Stanojković, T., Manojlović, N. and Ranković, B. (2018): Extracts of five Cladonia lichens as sources of biologically active compounds. - Farmacia 66(4): 644-651. https://doi.org/10.31925/farmacia.2018.4.13.

Lange, O. L., Schulze, E. D. and Koch, W. (1970): Experimentell-ökologische Untersuchungen an Flechten der Negev-Wüste. II. $\mathrm{CO}_{2}$-Gaswechsel und Wasserhaushalt von Ramalina maciformis (Del.) Bory am natürlichen Standort während der sommerlichen Trockenperiode. - Flora 159: 38-62. https://doi.org/10.1016/s0367-2530(17)31005-8

Matteucci, E., Occhipinti, A., Piervittori, R., Maffei, M. E. and Favero-Longo, S. E. (2017): Morphological, secondary metabolite and ITS (rDNA) variability within usnic acidcontaining lichen thalli of Xanthoparmelia explored at the local scale of rock out- 
crop in W-Alps. - Chemistry and Biodiversity 14(6): e1600483. https://doi.org/10.1002/ cbdv.201600483

Mázsa, K. (1994): Field studies on $\mathrm{CO}_{2}$ fixation of Cladonia furcata and Cladonia convoluta. - Cryptogamic Bot. 4: 207-211.

Mázsa, K., Mészáros, R. and Kalapos, T. (1998): Ecophysiological background of microhabitat preference by soil-living lichens in a sand grassland-forest mosaic; study plan and initial results. - Sauteria 9: 165-171.

Mázsa, K., Mészáros, R. and Kalapos, T. (1999): Ecophysiology of steppe mosses and lichens. In: Kovács-Láng, E., Molnár, E., Kröel-Dulay, Gy. and Barabás, S. (eds): Long term ecological research in the Kiskunság, Hungary. Institute of Ecology and Botany, Hungarian Academy of Sciences, Vácrátót, pp. 37-38.

McEvoy, M., Solhaug, K. A. \& Gauslaa, Y. (2007) Solar radiation screening in usnic acidcontaining cortices of the lichen Nephroma arcticum. - Symbiosis 43: 143-150.

Mitrović, T., Stamenković, S., Cvetković, V., Tošić, S., Stanković, M., Radojević, I., Stefanović, O., Čomić, L., Dačić, D., Ćurčić, M. and Marković, S. (2011): Antioxidant, antimicrobial and antiproliferative activities of five lichen species. - Int. J. Mol. Sci. 12(8): 5428-5448. https://doi.org/10.3390/ijms12085428

Mitrović, T. L., Stamenković, S. M., Cvetković, V. J., Radulović, N. S., Mladenović, M. Z., Stanković, M. S., Topuzović, M. D., Radojević, I. D., Stefanović, O. D., Vasić, S. M., Comić, L. R., Seklić, D. S., Obradović, A. D. and Marković, S. D. (2015): Contribution to the knowledge of the chemical composition and biological activity of the lichens Cladonia foliacea Huds. (Wild.) and Hypogymnia physodes (L.). - Oxidation Communications 38(4A): 2016-2032.

Molnár, K. and Farkas, E. (2010): Current results on biological activities of lichen secondary metabolites: a review. - Z. Naturforsch., Sect. C 65(3-4): 157-173. https://doi. org/10.1515/znc-2010-3-401

Molnár, K. and Farkas, E. (2011): Depsides and depsidones in populations of the lichen Hypogymnia physodes and its genetic diversity. - Ann. Bot. Fennici 48: 473-482. https:// doi.org/10.5735/085.048.0605

Moya, P., Škaloud, P., Chiva, S., García-Breijo, F. J., Reig-Armiñana, J., Vančurová, L. and Barren, E. (2015): Molecular phylogeny and ultrastructure of the lichen microalga Asterochloris mediterranea sp. nov. from Mediterranean and Canary Islands ecosystems. - Int. J. Syst. Evol. Microbiol. 65(6): 1838-1854. https://doi.org/10.1099/ijs.0.000185

Nash, III T. H. (2008): Lichen biology, 2nd ed. - University Press, Cambridge.

Nguyen, K.-H., Chollet-Krugler, M., Gouault, N. and Tomasi, S. (2013): UV-protectant metabolites from lichens and their symbiotic partners. - Natural Product Reports 30(12): 1490-1508. https://doi.org/10.1039/c3np70064j

Orange, A., James, P. W. and White, F. J. (2010): Microchemical methods for the identification of lichens, second ed. - British Lichen Society, London.

Pandir, D., Hilooglu, M. and Kocakaya, M. (2018): Assessment of anticytotoxic effect of lichen Cladonia foliacea extract on Allium cepa root tips. - Environ. Sci. Pollut. Res. 25(32): 32478-32490. https://doi.org/10.1007/s11356-018-3221-6

Peksa, O. and Škaloud, P. (2008): Changes in chloroplast structure in lichenized algae. Symbiosis 46: 153-160.

P.-Verseghy, K. (1976): Xerofiton zuzmófajok anatómiai vizsgálata. (Anatomical investigations on xerophytous lichen species). - Studia bot. hung. 11: 35-48.

R Core Team (2013): R: a language and environment for statistical computing. - Vienna, Austria: R Foundation for Statistical Computing. http://www.R-project.org/. 
Shukla, V., Patel, D. K., Bajpai, R., Semwal, M. and Upreti, D. K. (2016): Ecological implication of variation in the secondary metabolites in parmelioid lichens with respect to altitude. - Environ. Sci. Pollut. Res. 23(2): 1391-1397. https://doi.org/10.1007/s11356015-5311-z

Škaloud, P. and Peksa, O. (2008): Comparative study of chloroplast morphology and ontogeny in Asterochloris (Trebouxiophyceae, Chlorophyta). - Biologia 63(6): 873-880. https://doi.org/10.2478/s11756-008-0115-y

Smith, C. W., Aptroot, A., Coppins, B. J. et al. (eds) (2009): The lichens of Great Britain and Ireland. - British Lichen Society, London.

Solhaug, K. A. and Gauslaa, Y. (1996): Parietin, a photoprotective secondary product of the lichen Xanthoria parietina. - Oecologia 108: 412-418. https://doi.org/10.1007/ bf00333715

Solhaug, K. A. and Gauslaa, Y. (2001): Acetone rinsing - a method for testing ecological and physiological roles of secondary compounds in living lichens. - Symbiosis 30: 301-315.

Solhaug, K. A. and Gauslaa, Y. (2004): Photosynthates stimulate the UV-B induced fungal anthraquinones synthesis in the foliose lichen Xanthoria parietina. - Plant, Cell and Environment 27: 167-176. https://doi.org/10.1111/j.1365-3040.2003.01129.x

Stocker-Wörgötter, E. (2008): Metabolic diversity of lichen-forming ascomycetous fungi: culturing, polyketide and shikimate metabolite production, and PKS genes. - Natural Product Reports 25: 188-200. https://doi.org/10.1039/b606983p

Stocker-Wörgötter, E. (2015): Biochemical diversity and ecology of lichen-forming fungi: Lichen substances, chemosyndromic variation and origin of polyketide-type metabolites (biosynthetic pathways). - In: Upreti, D. K., Divakar, P. K., Shukla, V. and Bajpai, R. (eds): Recent advances in lichenology: modern methods and approaches in biomonitoring and bioprospection. 2. Springer, New Delhi, Heidelberg, New York, Dordrecht, London, pp. 161-180.

Stofer, S., Bergamini, A., Aragón, G. et al. (2006): Species richness of lichen functional groups in relation to land use intensity. - Lichenologist 38(4): 331-353. https://doi. org/10.1017/s0024282906006207

Verseghy, K., Kovács-Láng, E. and Mázsa, K. (1987): Diurnal and seasonal changes of thallus water content of xerothermic lichens. - Lichen Physiol. Biochem. 2: 31-44.

Vráblíková, H., McEvoy, M., Solhaug, K. A., Barták, M. and Gauslaa, Y. (2006): Annual variation in photoacclimation and photoprotection of the photobiont in the foliose lichen Xanthoria parietina. - J. Photochem. Photobiol. B: Biology 83: 151-162. https://doi. org/10.1016/j.jphotobiol.2005.12.019

Wirth, V., Hauck, M. and Schultz, M. (2013): Die Flechten Deutschlands. - Ulmer Verlag, Stuttgart, $1244 \mathrm{pp}$.

Yilmaz, M., Turk, A. O., Tay, T. and Kivanc, M. (2004): The antimicrobial activity of extracts of the lichen Cladonia foliacea and its (-)-usnic acid, atranorin, and fumarprotocetraric acid constituents. - Z. Naturforsch., Sect. C 59: 249-254. https://doi.org/10.1515/ znc-2004-3-423

Open Access statement. This is an open-access article distributed under the terms of the Creative Commons Attribution 4.0 International License (https://creativecommons.org/ licenses/by/4.0/), which permits unrestricted use, distribution, and reproduction in any medium, provided the original author and source are credited, a link to the CC License is provided, and changes - if any - are indicated. (SID_1) 